\title{
EFFECTS OF MANAGEMENT PRACTICES IN HIGHLAND PASTURES ON AGRONOMIC AND ENVIRONMENTAL OBJECTIVES
}

\author{
DufFKovÁ, R. ${ }^{1 *}$ - HAKRovÁ, P. ${ }^{2}-$ Brom, J. ${ }^{3}-$ FuČíK, P. ${ }^{1}$ - Novotná, K. ${ }^{3}$ \\ ${ }^{1}$ Research Institute for Soil and Water Conservation \\ Žabovřeská 250, 15627 Prague, Czech Republic \\ ${ }^{2}$ Administration of the National Park and Protective Landscape Area of Šmava \\ 1. máje 260, 38501 Vimperk, Czech Republic \\ ${ }^{3}$ Faculty of Agriculture, University of South Bohemia in České Budějovice \\ Studentská 1668, 37005 České Budějovice, Czech Republic \\ *Corresponding author \\ e-mail: duffkova.renata@vumop.cz \\ (Received $17^{\text {th }}$ Jul $2017 ;$ accepted $6^{\text {th }}$ Oct 2017)
}

\begin{abstract}
Resolution of plant diversity goals with the agricultural demands placed on grasslands may result in conflict between farmers and conservationists. To investigate options for reconciling these important issues implementable in the short-term within agro-environmental schemes, we analysed the impact of four years' management with grazing replaced by mowing on coordination of agricultural objectives, i.e. herbage yield, plant functional groups, nutrient contents and removal, forage value and plant diversity, i.e. species richness, Shannon-Wiener index, Ellenberg $\mathrm{N}$ indicator value. The study was carried out in three hillslope highland pasture sites (S1-S3) in the Šumava Mountains, Czech Republic, differing in soil properties and animal stocking rates, which were 0.92 in S1, 0.34 in S2, combined with mowing in some years and 0.73 in S3 LU ha ${ }^{-1}$. Some sections of each pasture site were twice yearly mowed. Our findings related to grazing combined or replaced with mowing were relevant to farmers' priorities acceptable for dairy cattle nutrition. Across sites, the herbage dry matter yield, herbage $\mathrm{P}, \mathrm{K}$ and $\mathrm{Mg}$ contents and removal, proportion of graminoids and Ellenberg $\mathrm{N}$ values decreased with mowing, but forage value and herbage $\mathrm{Ca}$ removal remained identical under both managements. Species richness, Shannon-Wiener index and herbage $\mathrm{Ca}$ content increased with mowing via spread of forbs and/or legumes. However, to achieve a merit, short-term grazing exclusion with mowing has to take into account site-specific soil nutrient conditions. Very high soil P availability prevented from the increase in species richness with mowing (S3). Contrarily, in sites with lower soil $\mathrm{P}$ availability, but different availability of other nutrients (S1, S2), mowing fostered number and/or proportions of forbs and/or legumes.
\end{abstract}

Keywords: grazing, mowing, grassland, available soil nutrients, biodiversity, above-ground biomass

\section{Introduction}

Resolution of plant diversity goals with the agricultural demands placed on grasslands is an important issue of agri-environmental policies (Isselstein et al., 2005). Improvement in plant diversity (species richness and species evenness) is linked with extensive grassland management, which is often accompanied by a decline in agricultural production (Plantureux et al., 2005; Blüthgen et al., 2012). Hence, plant species diversity, forage quality, and biomass production may not correlate, resulting in conflict between farmers and conservationists (Pavlů et al., 2006). To resolve these issues, an effective agro-environment subsidy policy is needed to compensate for production losses. In addition, positive effects of vegetation diversity on production 
stability, efficient nutrient and water use, and forage quality may encourage farmers to cooperate (Sanderson et al., 2004; Wrage et al., 2011).

The plant diversity-productivity relationship varies strongly along with site conditions and is integrated in herbage nutrient contents, which reflect plant growth, plant functional composition, land use, and management practices (Klaus et al., 2013a).

Extensive grazing, the predominant farming system in upland and marginal areas, can deliver both economic benefits and increase in grassland biodiversity, reducing the environmental impact of animal production (Marriott et al., 2005; Rose et al., 2012). Plant relations in pastures influence biodiversity responses through both positive (e.g., facilitation, $\mathrm{N}_{2}$ fixation, hydraulic lift) and negative interactions (e.g., competitive exclusion, allelopathy) (Sanderson et al., 2004). Grazing at a stocking rate (SR) of fewer than 1.5 livestock units (LU) $\mathrm{ha}^{-1}$ has the potential to facilitate restoration of sward heterogeneity and thus floral and faunal diversity, by selective defoliation through grazing, treading, nutrient cycling, and propagule dispersal (Zhang et al., 2013; Dubeux et al., 2014; Quan et al., 2015). A variety of vegetation structures can develop regardless soil conditions under the influence of grazing animals and their foraging strategy resulting to structural patterns of short- and high-growing vegetation patches (Gilhaus et al., 2014). Short-growing species with higher fodder values are preferably grazed and, hence, the likelihood of their endozoochorous dispersion is supposed (Gilhaus et al., 2017).

To restore plant diversity in soils with intermediate nutrient content, mowing of grazed pastures has been demonstrated to reduce nutrient availability, especially phosphorus (Isselstein et al., 2005; Blüthgen et al., 2012). Alternating mowing and grazing should promote coexistence of multiple forbs and grasses and balance nutrient limitation (Mládková et al., 2015). Plantureux et al. (2005) considered the combination of an early cut and late grazing as a compromise between quality forage production and biodiversity maintenance for the conditions of Central Europe. A combination of grazing and mowing can also enhance the opportunity for regeneration of seedlings, if a closed canopy exists in grazed plant communities (Plantureux et al., 2005).

Our study was conducted in three highland pasture sites to investigate options for reconciling plant diversity and agronomy targets implementable in the short-term within agro-environmental schemes. We evaluated the effects of four years' mowing as opposed to grazing on agronomic factors and plant diversity parameters. Prior to our research, we hypothesized that i) short-term mowing could improve plant diversity parameters (species richness, Shannon-Wiener index, and Ellenberg N indicator), but ii) eventually deteriorate agronomic objectives (herbage dry matter yield, plant functional groups, herbage nutrient content and removal, tetany ratio, and forage value). However, a complex of site nutrient conditions allow specific adaptations to management changes (Gilhaus and Hölzel, 2016). Hence, we also took into account the applicability of shortterm grazing exclusion with mowing to plant diversity improvement related to different soil site conditions and grazing types.

\section{Materials and methods}

\section{Study site}

The study took place 2011-2014 in Pasečná $\left(48^{\circ} 36^{\prime} 18.0^{\prime \prime} \mathrm{N} ; 1^{\circ} 07^{\prime} 12.0^{\prime \prime} \mathrm{E}\right)$, an upland, geomorphologically heterogeneous, plateau near the Czech-Austrian border, in the foothills of the Šumava Mountains (Fig. 1). Mean altitude of the study site is 822.6 $\mathrm{m}$ a.s.l. with range from 781.4 to $882.4 \mathrm{~m}$ a.s.l. The region is cool with mean air 
temperatures annually and in the growing season of $5.5^{\circ} \mathrm{C}$ and $11.2{ }^{\circ} \mathrm{C}$, respectively, and average annual and growing season precipitation of $910 \mathrm{~mm}$ and $510 \mathrm{~mm}$, respectively. Parent rock in Pasečná is granite. The soils are predominantly acidic, Haplic to Gleyed Cambisols, and Gleysols with distinct stand-conditioned dissimilarities in soil texture, soil depth, and soil water regime. In 1993, the study area changed from intensive cultivation to pasture. Until 2011, the land was under a rotational pasturing with mean SR of $0.7 \mathrm{LU} \mathrm{ha}^{-1}$, with the lowest SR in S2 due to the combination with occasional mowing.

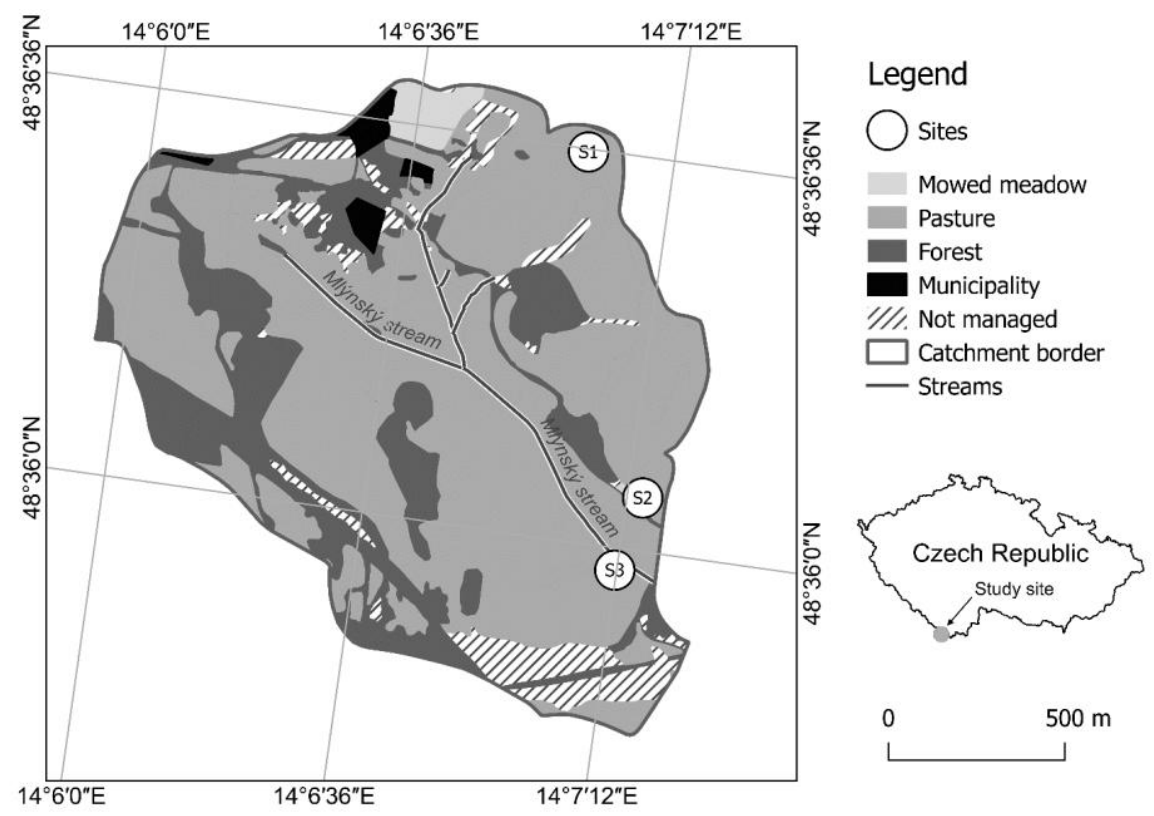

Figure 1. The catchment in Pasečná; experimental sites S1-S3

Three experimental sites differing in soil properties and SR (Table 1) were selected randomly in hillslope geomorphological zones (recharge - S1, transport - S2, discharge - S3). Site S3 consisted of tile-drained soil.

Table 1. Site characteristics, management, stocking rate, plant cover and plant species (2011-2014)

\begin{tabular}{|c|c|c|c|c|c|c|}
\hline Site & \multicolumn{2}{|c|}{ S1 } & \multicolumn{2}{|c|}{ S2 } & \multicolumn{2}{|c|}{ S3 } \\
\hline Altitude & \multicolumn{2}{|c|}{$837 \mathrm{~m}$ a.s.1 } & \multicolumn{2}{|c|}{$797 \mathrm{~m}$ a.s.l } & \multicolumn{2}{|c|}{$786 \mathrm{~m}$ a.s.1 } \\
\hline Soil type & \multicolumn{2}{|c|}{ Leptic Cambisol, loam-sand } & \multicolumn{2}{|c|}{ Haplic Cambisol, sand-loam } & \multicolumn{2}{|c|}{ Haplic Gleysol, loam-sand } \\
\hline Management & Mowed & Grazed (SR) & Mowed & $\begin{array}{c}\text { Grazed } \\
\text { combined with } \\
\text { mowed (SR) }\end{array}$ & Mowed & Grazed (SR) \\
\hline 2011 & TM & TRG (0.76) & TM & $\begin{array}{c}\mathrm{SM}+\mathrm{AG} \\
(0.40)\end{array}$ & TM & TRG $(0.50)$ \\
\hline 2012 & TM & TRG $(0.88)$ & $\mathrm{TM}$ & CG (0.56) & $\mathrm{TM}$ & CG (0.56) \\
\hline 2013 & TM & TRG $(0.95)$ & TM & TM & TM & CG (0.93) \\
\hline 2014 & TM & TRG (1.1) & TM & $\begin{array}{c}\text { SM + TRG } \\
\quad(0.41)\end{array}$ & $\mathrm{TM}$ & CG (0.93) \\
\hline
\end{tabular}




\begin{tabular}{|c|c|c|c|c|c|c|}
\hline Mean SR & & 0.92 & & 0.34 & & 0.73 \\
\hline $\begin{array}{c}\text { Mean cover } \\
\text { of vascular } \\
\text { plants }(\%), \\
\text { G:L:F }\end{array}$ & $\begin{array}{c}86 \\
55: 1: 30\end{array}$ & $\begin{array}{c}84 \\
64: 4: 16\end{array}$ & $\begin{array}{c}84 \\
50: 11: 23\end{array}$ & $\begin{array}{c}79 \\
56: 8: 15\end{array}$ & $\begin{array}{c}89 \\
73: 1: 15\end{array}$ & $\begin{array}{c}85 \\
66: 7: 12\end{array}$ \\
\hline $\begin{array}{l}\text { Total N } \\
\text { G:L:F }\end{array}$ & $\begin{array}{c}41 \\
11: 1: 29\end{array}$ & $\begin{array}{c}34 \\
11: 3: 20\end{array}$ & $\begin{array}{c}45 \\
12: 6: 27\end{array}$ & $\begin{array}{c}44 \\
11: 6: 27\end{array}$ & $\begin{array}{c}39 \\
15: 3: 21\end{array}$ & $\begin{array}{c}35 \\
13: 2: 20\end{array}$ \\
\hline $\begin{array}{c}\text { Dominant G } \\
(\%)\end{array}$ & $\begin{array}{c}\text { Dactylis } \\
\text { glomerata (23) } \\
\text { Lolium perenne } \\
\text { (14.9) } \\
\text { Poa pratensis } \\
(10.5)\end{array}$ & $\begin{array}{c}\text { D. glomerata } \\
(31.8) \\
\text { L. perenne } \\
(15.4) \\
\text { P. pratensis } \\
(6.3) \\
\text { Poa trivialis } \\
(5.6)\end{array}$ & $\begin{array}{c}\text { Festuca. rubra } \\
(14.7) \\
\text { Agrostis } \\
\text { capillaris (14.6) } \\
\text { P. pratensis } \\
(8.8) \\
\text { D. glomerata } \\
(6.3)\end{array}$ & $\begin{array}{c}\text { A. capillaris } \\
(25.1) \\
\text { F. rubra }(9.9) \\
\text { P. pratensis } \\
\quad(7.6) \\
\text { D. glomerata } \\
(7.1)\end{array}$ & $\begin{array}{l}\text { A. capillaris } \\
\quad(33.9) \\
\text { P. pratensis } \\
(21.8) D . \\
\text { glomerata } \\
\quad(7.5)\end{array}$ & $\begin{array}{l}\text { A. capillaris } \\
\text { (41.7) } \\
\text { P. pratensis } \\
(15.2)\end{array}$ \\
\hline $\begin{array}{c}\text { Dominant L } \\
(\%)\end{array}$ & $\begin{array}{l}\text { Trifolium repens } \\
\text { (1.1) }\end{array}$ & $\begin{array}{l}\text { T. repens } \\
\quad(3.5)\end{array}$ & $\begin{array}{l}\text { T. repens }(4.7) \\
\text { Trifolium } \\
\text { pratense }(4.2)\end{array}$ & $\begin{array}{c}\text { T. repens }(4) \\
\text { T. pratense } \\
\text { (2.4) }\end{array}$ & $\begin{array}{l}\text { Lathyrus } \\
\text { pratensis } \\
\quad(0.6)\end{array}$ & $\begin{array}{l}\text { T. repens } \\
\quad(6.5)\end{array}$ \\
\hline $\begin{array}{l}\text { Dominant F } \\
(\%)\end{array}$ & $\begin{array}{c}\text { Anthriscus } \\
\text { sylvestris }(8.6) \\
\text { Heracleum } \\
\text { sphondylium } \\
\text { (6.9), Taraxacum } \\
\text { sect. ruderalia } \\
(2.6), \text { Pimpinella } \\
\text { major }(2.5), \\
\text { Achillea } \\
\text { millefolium (2.4), } \\
\text { Veronica } \\
\text { chamaedrys }(2.3)\end{array}$ & $\begin{array}{l}\text { T. sect. } \\
\text { ruderalia } \\
\quad(9.4)\end{array}$ & $\begin{array}{c}\text { T. sect. ruderalia } \\
\text { (4) } \\
\text { A. sylvestris } \\
(2.7) \\
\text { Hypericum } \\
\text { maculatum (2.6) } \\
\text { V. chamaedrys } \\
(2.1) \\
\text { Galium album } \\
(2.1)\end{array}$ & $\begin{array}{c}\text { T. sect. } \\
\text { ruderalia (3.9) }\end{array}$ & $\begin{array}{l}\text { Ranunculus } \\
\text { repens }(8.1)\end{array}$ & $\begin{array}{c}\text { R. repens } \\
\text { (3.3) } \\
\text { T. sect. } \\
\text { ruderalia (2) }\end{array}$ \\
\hline
\end{tabular}

SR - stocking rate, $\mathrm{LU}$ ha $^{-1}$; TM - twice yearly mowed; SM - spring mowing; AG - autumn grazing; TRG - twice yearly rotational grazing; $\mathrm{CG}$ - continuous grazing; $\mathrm{N}$ - number of species; $\mathrm{G}$ - grasses; $\mathrm{L}$ - legumes; F - forbs

Stand-typical plant community was not described for the sites until 2011, but some dominant plants were already obvious (Table 1).

The effects of grazing (combined with mowing in S2) and mowing were observed in separate sections of each site from 2011-2014 (Fig. 1). Grazing regimes differed among the experimental sites and, in S2 and S3, from year to year (Table 1). Mean SR was generally low (0.66 LU ha $\left.{ }^{-1}\right)$, although in S1, which had the highest SR (0.92 LU ha $\left.{ }^{-1}\right)$ and the content of available plant nutrients, a heavy cattle load for about three weeks each year considerably damaged the plant cover. Site S2, where grazing was combined with mowing in 2011 and 2014 and replaced with mowing in 2013, had the lowest mean SR at $0.34 \mathrm{LU} \mathrm{ha}^{-1}$. Grazing in S3 was carried out throughout the season with a mean SR of $0.73 \mathrm{LU} \mathrm{ha}^{-1}$.

Mowed areas of $60 \mathrm{~m}^{2}(6 \times 10 \mathrm{~m})$ enclosed by wooden fences were established randomly in each site in spring 2011 to be representative of plant community. Within this area, four $1 \mathrm{~m}^{2}$ plots were delineated to assess herbage dry matter (DM) yield, weight proportions of functional plant groups, and herbage nutrient content by probability sampling. In addition, a permanent $16 \mathrm{~m}^{2}(4 \mathrm{x} 4 \mathrm{~m})$ plot was delineated for phytosociological monitoring. 
For monitoring DM yield and herbage properties associated with grazing in S1 and S3 and with the combination of grazing and mowing in S2, four moveable $1 \mathrm{~m}^{3}$ wire cages were placed randomly on each site in spring prior to the grazing season. Twice yearly, in accordance with mowed areas, the cages were moved several metres and the biomass under the cage was cut. Prior to the cage shift, the above-ground biomass at the new placement area was cut to a similar height of the grazed area. A permanent $16 \mathrm{~m}^{2}$ plot was also established in grazed areas.

Soil single samples were taken in accordance with herbage samples each year 20122014 from soil layers of grazed and mowed sections at 4-8 cm and 10-14 cm depth to analyse $\mathrm{pH}(\mathrm{KCl})$, available plant nutrients, and organic matter content (Table 2). Available plant nutrient levels extracted using Mehlich III solution were categorized according to Sáňka and Materna (2004) in S1 as good/satisfactory (Ca, Mg), very high/high (K), and good (P). In S2, nutrient levels were satisfactory/low (Ca), low (Mg), low/satisfactory $(\mathrm{K})$, and good/satisfactory $(\mathrm{P})$; and in S3 satisfactory (Ca, $\mathrm{Mg}$ ), satisfactory/low $(\mathrm{K})$, and very high $(\mathrm{P})$. The organic matter content ranged from good to very high $(3.81 \% \pm$ s.d. 1.79$)$.

Table 2. Mean soil $p H$, available soil nutrient content $\left(P, K, M g, C a, N_{\text {min }}\right)$, organic carbon $\left(C_{\text {org }}\right)$, and total nitrogen $\left(N_{\text {tot }}\right)$ content in experimental sites under grazing and mowing from 2012-2014 (sampled simply twice per year at 4-8 and 10-14 cm)

\begin{tabular}{|c|c|c|c|c|c|c|c|c|c|c|c|c|c|c|c|c|}
\hline \multirow[t]{2}{*}{ Site } & \multicolumn{2}{|c|}{ pH (KCl) } & \multicolumn{2}{|c|}{$P\left(\mathrm{mg} \mathrm{kg}^{-1}\right)$} & \multicolumn{2}{|c|}{$\mathrm{K}\left(\mathrm{mg} \mathrm{kg}^{-1}\right)$} & \multicolumn{2}{|c|}{$\mathrm{Mg}\left(\mathrm{mg} \mathrm{kg}^{-1}\right)$} & \multicolumn{2}{|c|}{$\mathrm{Ca}\left(\mathrm{mg} \mathrm{kg}^{-1}\right)$} & \multicolumn{2}{|c|}{$\mathbf{N}_{\min }\left(\mathrm{mg} \mathrm{kg}^{-1}\right)$} & \multicolumn{2}{|c|}{$\mathrm{C}_{\text {org }}(\%)$} & \multicolumn{2}{|c|}{$\mathbf{N}_{\text {tot }}(\%)$} \\
\hline & $\begin{array}{l}\vec{D} \\
\mathbb{N} \\
\vdots \\
0\end{array}$ & $\begin{array}{l}\text { D } \\
\text { 岁 } \\
\stackrel{g}{g}\end{array}$ & $\begin{array}{l}\vec{D} \\
\mathbb{E} \\
\text { U. }\end{array}$ & $\begin{array}{l}\vec{D} \\
\text { 今े } \\
\text { ¿ }\end{array}$ & $\begin{array}{l}\vec{D} \\
\mathbb{E} \\
\text { d. }\end{array}$ & $\begin{array}{l}\text { Dू } \\
\text { בे } \\
\text { ఏ }\end{array}$ & 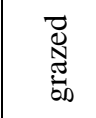 & 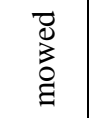 & $\begin{array}{l}\overrightarrow{\mathscr{D}} \\
\mathbb{E} \\
\text { d. }\end{array}$ & $\begin{array}{l}\vec{D} \\
\text { בे } \\
0 \\
\Xi\end{array}$ & 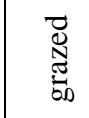 & $\begin{array}{l}\text { J } \\
\text { zे } \\
\stackrel{0}{\Xi}\end{array}$ & $\begin{array}{l}\vec{D} \\
\mathbb{N} \\
\text { b. }\end{array}$ & 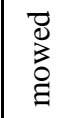 & 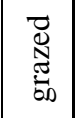 & $\begin{array}{l}\text { ठ } \\
\text { ż } \\
\stackrel{g}{\Xi}\end{array}$ \\
\hline S1 & 5.57 & 5.04 & 65.0 & 54.3 & 562.8 & 350.3 & 142.0 & 89.7 & 1982 & 1538 & 23.0 & 19.9 & 3.39 & 3.04 & 0.46 & 0.38 \\
\hline S2 & 4.84 & 4.39 & 56.6 & 42.9 & 85.5 & 170.2 & 30.6 & 29.8 & 1172 & 791 & 10.3 & 19.9 & 2.83 & 2.67 & 0.28 & 0.27 \\
\hline S3 & 4.11 & 4.23 & 251.2 & 153.0 & 131.7 & 90.2 & 84.8 & 69.7 & 1269 & 1008 & 13.4 & 14.1 & 5.98 & 4.22 & 0.46 & 0.41 \\
\hline Mean & 4.84 & 4.59 & 128.2 & 91.5 & 270.2 & 210.2 & 89.1 & 69.7 & 1474 & 1112 & 16.0 & 18.3 & 4.14 & 3.44 & 0.41 & $0.37 \mid$ \\
\hline
\end{tabular}

\section{Herbage biomass sampling}

The $1 \mathrm{~m}^{2}$ plots in both management areas were cut in early June and late September to $5 \mathrm{~cm}$ above the soil surface. Herbage was weighed, and proportions (\% by weight) of graminoids (Poaceae, Cyperaceae, and Juncaceae families), legumes, and other forbs, considered functional plant groups, were determined. Herbage was desiccated and dry matter (DM) content determined. Dry matter herbage yield in tons $\mathrm{ha}^{-1}$ was calculated for each cut and combined for an annual DM herbage yield. Dried herbage from all $1 \mathrm{~m}^{2}$ plots was crushed, and $100 \mathrm{~g}$ samples were weighed for determination of $\mathrm{N}, \mathrm{P}, \mathrm{K}, \mathrm{Ca}$, and $\mathrm{Mg}$ content in $\mathrm{g} \mathrm{kg}^{-1}$. Herbage $\mathrm{N}$ content was determined by the Kjeldahl method (ISO 11261, 1995). To determine P, K, Ca, and Mg content, samples were digested by nitric and perchloric acid in an open system, and concentrations of the elements in solution were determined spectrophotometrically by continuous flow analyser $(\mathrm{P})$ and atomic absorption spectrometer $(\mathrm{K}, \mathrm{Ca}$, and $\mathrm{Mg})$. The tetany ratio $[\mathrm{K}:(\mathrm{Ca}+\mathrm{Mg})]$ was determined from values of $\mathrm{K}, \mathrm{Ca}$, and $\mathrm{Mg}$ content converted into milliequivalents per kilogram (Kayser and Isselstein, 2005). Annual N, P, K, Ca, and Mg removal in kg ha ${ }^{-1}$ by harvested biomass was calculated by multiplying DM herbage yield by the content of 
each nutrient for each cut. Values obtained for both cuts were combined. To estimate the limitation of grassland growth by nutrients nutrient ratios $(\mathrm{N}: \mathrm{P}, \mathrm{N}: \mathrm{K}, \mathrm{K}: \mathrm{P})$ were calculated according to Koerselman and Mueleman (1996), Olde Ventering et al. (2003) and Güssewell (2004). N limitation was designated as $\mathrm{N}: \mathrm{P} \leq 10$ and $\mathrm{N}: \mathrm{K}<2.1$, NP colimitation as $\mathrm{N}: \mathrm{P}>10$ and $<16$ and $\mathrm{K}: \mathrm{P}>3.4, \mathrm{~K}($ co-)limitation as $\mathrm{N}: \mathrm{K}>2.1$ and $\mathrm{K}: \mathrm{P}<$ 3.4 and $\mathrm{P}$ limitation as $\mathrm{N}: \mathrm{P}>16$.

\section{Phytocenological assessment}

The percent cover of vascular plant species (nomenclature following Kubát et al., 2002) was estimated visually in May, July, and late September/early October in 20112014 in the permanent $4 \times 4 \mathrm{~m}$ plots. The first phytocenological assessment was conducted prior to grazing. The number of vascular plant species, Shannon-Wiener index (SW index), forage value (FV), and the Ellenberg nutrient indicator values (EIVN) were calculated. Classification of species followed Regal (1980) and Veselá et al. (2009). The Ellenberg N indicator value (Ellenberg et al., 1992) was calculated as the mean of indicator values weighted by extent of cover of each species.

\section{Statistical analysis}

To evaluate the effects of management, site characteristics, and management/site (MS) interaction on agronomic factors and plant diversity, the within-subject ANOVA model (R package nlme; Pinheiro et al., 2016) was used. To take into account the effect of repetition (pseudo-replication), the random factor (sampling date) was nested in site and in experimental year (temporal change) within the ANOVA model. Backward selection based on marginality rules was used for exclusion of non-significant effects from the ANOVA models. Reduced models were compared to the previous models using the Akaike Information Criterion. Post hoc comparison of the differences among tested groups was based on pairwise t-tests with $p$-values adjusted by the Holm correction (Pinheiro et al., 2016). Normality of the data was tested by the Shapiro-Wilk test. Data with non-normal distribution were transformed either by logarithmic transformation or by rank transformation in which the function rntransform from $\mathrm{R}$ package GenABEL (GenABEL project developers, 2013) was used. Relationships among measured variables were assessed by Pearson's correlation coefficient. All statistical analyses were processed using R (Pinheiro et al., 2016).

\section{Results}

\section{Herbage biomass parameters}

Herbage DM yield in 2011-2014 was significantly affected by management (Fig. 2, Table 3). Mean herbage DM yield decreased by 1.31 tons ha ${ }^{-1}$ with mowing (Table 4). The highest mean herbage DM yield was found in S1 (6.97 tons ha $\left.{ }^{-1}\right)$, associated with satisfactory to very high available soil nutrient content (Table 2), which produced similar herbage DM yields under both managements in 2011-2013 (mowed 7.02, grazed 6.98 tons $^{-1} \mathrm{a}^{-1}$. However, in 2014, the herbage DM yield in S1 dropped significantly in mowed plots (4.90 tons ha ${ }^{-1}$ ) compared to grazed (8.89 tons ha ${ }^{-1}$ ). In S2 and S3, mowing decreased mean herbage DM yield from 5.68 to 4.32 tons ha $^{-1}$ and from 7.41 to 5.88 tons $\mathrm{ha}^{-1}$, respectively. 


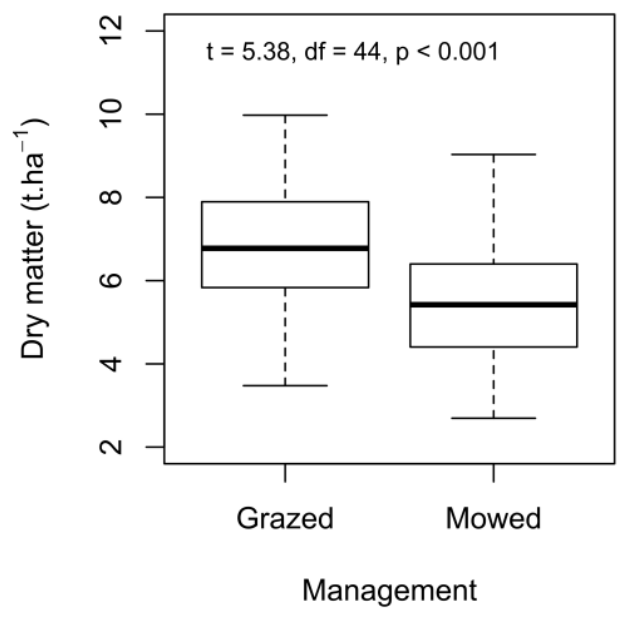

Figure 2. Herbage dry matter yield of all sites associated with management

Table 3. The effect of predictors on studied parameters expressed by F-ratios in withinsubject ANOVA model

\begin{tabular}{|c|c|c|c|c|}
\hline Parameters $\quad$ Predictors & Management & Site & M-S interaction & Transformation \\
\hline Proportion of graminoids & $25.43^{* * *}$ & $17.92^{* * *}$ & $9.45^{* * *}$ & $\operatorname{rank}(\mathrm{x})$ \\
\hline Proportion of legumes & 0.01 n.s. & $20.89^{* * *}$ & $43.62^{* * *}$ & $\operatorname{rank}(\mathrm{x})$ \\
\hline Proportion of forbs & $17.82^{* * *}$ & $7.65^{* *}$ & $4.88^{* *}$ & $\ln (x+1)$ \\
\hline Herbage DM yield & $28.98^{* * *}$ & Excl. & Excl. & Including 2011 \\
\hline Herbage $\mathrm{N}$ content & Excl. & $62.20^{* * *}$ & Excl. & \\
\hline Herbage $\mathrm{P}$ content & $11.46^{* *}$ & $4.81^{*}$ & Excl. & \\
\hline Herbage $\mathrm{K}$ content & $43.99^{* * *}$ & $194.59^{* * *}$ & Excl. & \\
\hline Herbage Ca content & $21.76^{* * *}$ & $3.58^{+}$ & $20.99^{* * *}$ & $1 / \ln (\mathrm{x})$ \\
\hline Herbage Mg content & $4.71^{*}$ & $104.65^{* * *}$ & Excl. & $\ln (\ln (x))$ \\
\hline Tetany ratio & $79.78^{* * *}$ & $28.26^{* * *}$ & $5.16^{*}$ & $\ln (\mathrm{x})$ \\
\hline Herbage $\mathrm{N}$ removal & $46.07^{* * *}$ & Excl. & Excl. & $\ln (x)$ \\
\hline Herbage $P$ removal & $40.24^{* * *}$ & Excl. & Excl. & \\
\hline Herbage $\mathrm{K}$ removal & $50.56^{* * *}$ & $26.29^{* * *}$ & Excl. & $\ln (x)$ \\
\hline Herbage Ca removal & 1.64 n.s. & $11.78^{* *}$ & $15.85^{* * *}$ & $\ln (\mathrm{x})$ \\
\hline Herbage $\mathrm{Mg}$ removal & $44.28^{* * *}$ & $14.68^{* * *}$ & Excl. & $\ln (\mathrm{x})$ \\
\hline Forage value & Excl. & $4.34^{*}$ & Excl. & \\
\hline Species richness & $45.23^{* * *}$ & $50.24^{* * *}$ & $4.97^{*}$ & \\
\hline SW index & $8.93^{* *}$ & $19.91^{* * *}$ & Excl. & \\
\hline Ellenberg $\mathrm{N}$ & $5.52^{*}$ & $102.92^{* * *}$ & Excl. & \\
\hline
\end{tabular}

$* * * P<0.001, * * P<0.01, * P<0.05,+P<0.1$, n.s. - not significant, Excl. - excluded, $\mathrm{M}-$ Management, $S$ - Site 
Table 4. Mean management values in S1-S3 sites in proportion of functional groups (\%), herbage DM yield $\left(t h \mathrm{~h}^{-1}\right)$, herbage nutrient content $\left(\mathrm{g} \mathrm{kg}^{-1}\right)$, tetany ratio, nutrient herbage removal $\left(\mathrm{kg} \mathrm{ha}^{-1}\right)$, forage value, species richness, Shannon-Wiener index, and Ellenberg $\mathrm{N}$ indicator value

\begin{tabular}{|c|c|c|c|c|c|c|c|c|c|c|c|}
\hline 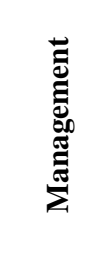 & $\stackrel{\triangleq}{\mathscr{n}}$ & 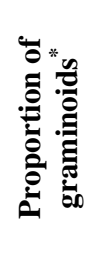 & 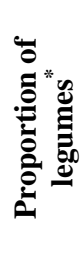 & 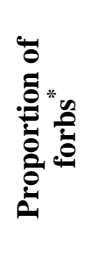 & 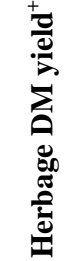 & 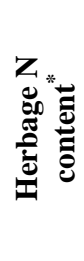 & 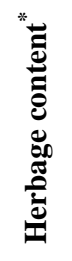 & 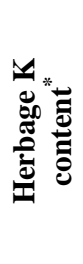 & 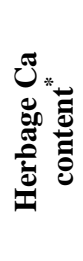 & 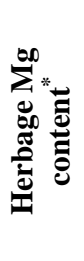 & 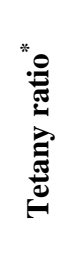 \\
\hline \multirow{4}{*}{ Grazed } & S1 & 88.1 & 2.12 & 9.8 & 7.49 & 19.3 & 3.55 & 34.4 & 5.53 & 1.56 & 2.21 \\
\hline & S2 & 84.8 & 2.73 & 12.5 & 5.68 & 19.0 & 3.38 & 25.4 & 7.95 & 1.70 & 1.33 \\
\hline & S3 & 91.4 & 1.58 & 7.0 & 7.41 & 21.3 & 3.56 & 22.5 & 5.53 & 2.37 & 1.26 \\
\hline & All sites & 88.4 & 2.1 & 9.8 & 6.86 & 19.86 & 3.50 & 27.43 & 6.33 & 1.93 & 1.60 \\
\hline \multirow{5}{*}{ Mowed } & S1 & 77.7 & 0.62 & 21.7 & 6.46 & 17.8 & 3.20 & 29.0 & 8.56 & 1.68 & 1.48 \\
\hline & S2 & 65.4 & 17.4 & 17.3 & 4.32 & 19.5 & 3.30 & 22.4 & 11.55 & 1.69 & 0.88 \\
\hline & S3 & 91.6 & 0.32 & 8.1 & 5.88 & 20.3 & 3.28 & 17.9 & 5.47 & 2.43 & 1.04 \\
\hline & All sites & 78.2 & 6.1 & 15.7 & 5.55 & 19.24 & 3.26 & 23.12 & 8.53 & 1.88 & 1.13 \\
\hline & & 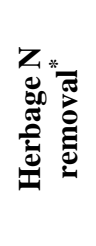 & 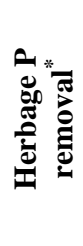 & 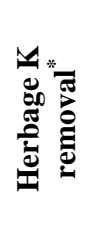 & 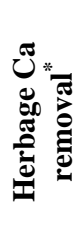 & 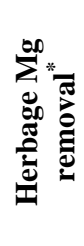 & 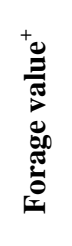 & 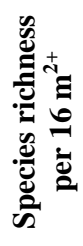 & 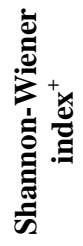 & 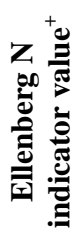 & \\
\hline \multirow{4}{*}{ Grazed } & S1 & 132.0 & 24.5 & 247.5 & 37.1 & 11.4 & 73.6 & 15.3 & 1.74 & 6.42 & \\
\hline & S2 & 104.2 & 18.4 & 144.1 & 40.4 & 9.19 & 63.2 & 23.4 & 2.25 & 3.97 & \\
\hline & S3 & 153.0 & 25.6 & 163.6 & 38.4 & 17.3 & 64.7 & 18.6 & 1.83 & 4.39 & \\
\hline & All sites & 129.7 & 22.8 & 185.1 & 38.6 & 12.6 & 67.2 & 19.1 & 1.94 & 4.92 & \\
\hline \multirow{4}{*}{ Mowed } & S1 & 98.3 & 18.4 & 176.3 & 44.6 & 8.7 & 71.0 & 20.8 & 2.14 & 5.91 & \\
\hline & S2 & 75.1 & 12.8 & 89.2 & 42.1 & 6.5 & 67.0 & 26.4 & 2.48 & 3.71 & \\
\hline & S3 & 110.5 & 18.0 & 98.7 & 27.0 & 12.6 & 69.1 & 20.3 & 1.84 & 4.25 & \\
\hline & All sites & 94.6 & 16.4 & 121.4 & 37.9 & 9.3 & 69.1 & 22.5 & 2.15 & 4.62 & \\
\hline
\end{tabular}

${ }^{*}$ Values from 2012-2014, ${ }^{+}$values from 2011-2014

Proportion of functional groups was significantly affected by management for graminoids and forbs and by site and M-S interaction for all groups (Fig. 3, Table 3). With mowing, the proportion of graminoids decreased in S1 and S2 accompanied by increase in forbs (in both sites) and legumes (in S2), while legumes decreased in S1 and S3 (Table 4). The increase of high Ca demanding forbs was significantly correlated to decreased soil $\mathrm{Ca}$ availability in $\mathrm{S} 1(r=-0.62, p<0.05, F=6.36, d f=11)$. The increase of legumes in $\mathrm{S} 2$ was positively correlated with soil K availability $(r=0.72, p<0.05, F$ $=6.49, d f=7$ ). The decrease in legumes (Trifolium repens) in $\mathrm{S} 1$ and $\mathrm{S} 3$ was connected with soil $\mathrm{Mg}$ depletion $(r=0.42, p<0.05, F=4.78, d f=23)$. 
a)

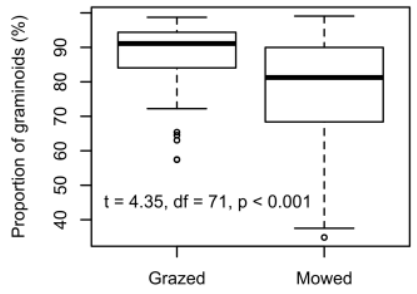

b)

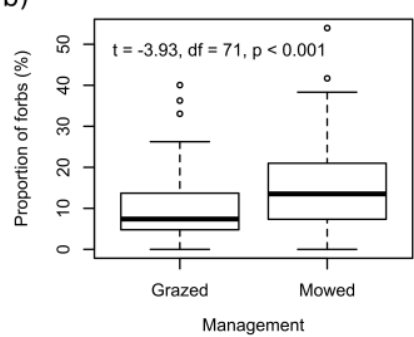

c)

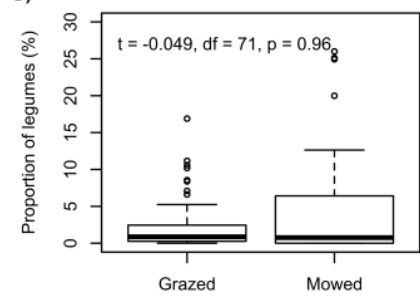

Figure 3. Proportions of graminoids (a), forbs (b), and legumes (c) associated with management

a)

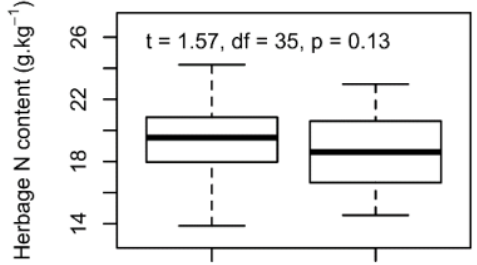

c)

e)

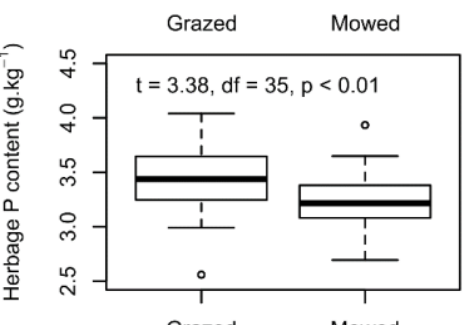

Grazed Mowed f)

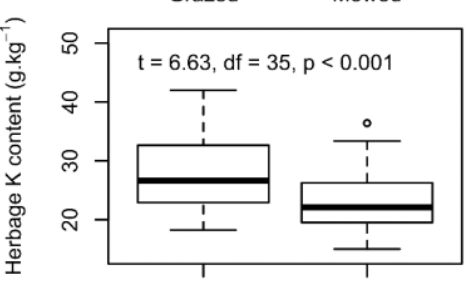

g)

i)

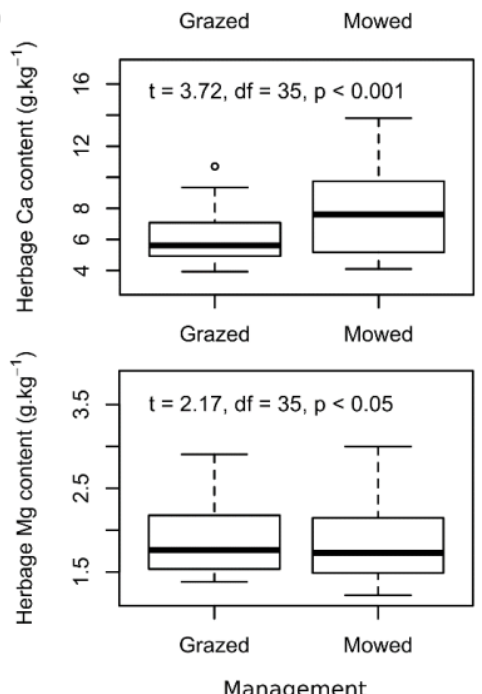

b) -

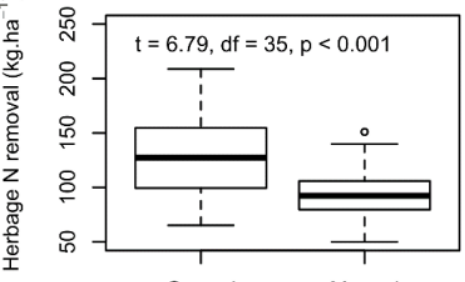

d)

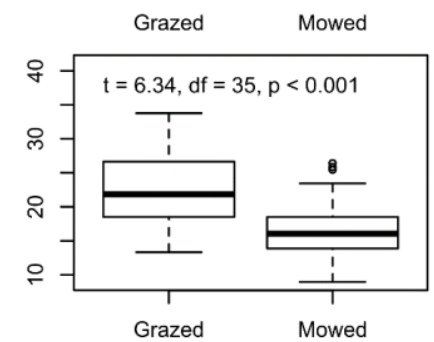

f)

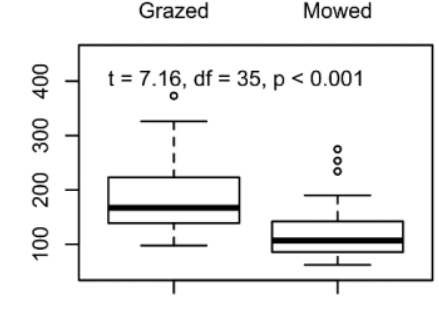

h)

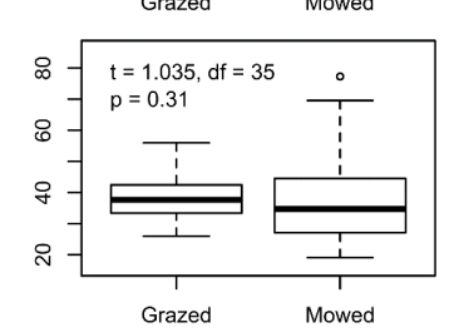

j)

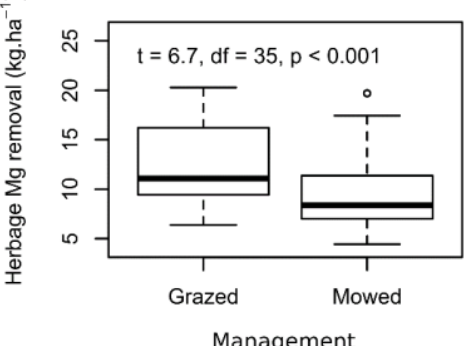

Figure 4. The herbage $N(a, b), P(c, d), K(e, f), C a(g, h)$, and $M g(i, j)$ content and removal associated with management 
Herbage nutrient content was significantly affected by management $(\mathrm{P}, \mathrm{K}, \mathrm{Mg}$, and $\mathrm{Ca}$ ), site (all nutrients), and M-S interaction (Ca) (Fig. 4, Table 3). Mowing depleting available soil nutrients by herbage removal decreased herbage $\mathrm{P}, \mathrm{K}$, and $\mathrm{Mg}$ content (Table 4) and altered the pattern of functional plant groups' occurrence. Across all sites, the reduction in herbage $\mathrm{K}$ content with mowing correlated strongly with depletion of soil $\mathrm{K}$ availability ( $r=0.60, p<0.001, F=16.87, d f=31$ ). Conversely, the herbage $\mathrm{Ca}$ content increased with mowing, which was significantly correlated with decrease in herbage DM yield (Fig. 5) and the proportion of graminoids $(\mathrm{r}=-0.78, p<0.001, F=$ 214.4, $d f=143)$ and with increase in forbs in S1 and S2 $(r=0.61, p<0.001, F=27.12$, $d f=47$ and $r=0.44, p<0.01, F=11.09, d f=47)$ and legumes in $\mathrm{S} 2(\mathrm{r}=0.65, p<$ $0.001, F=34.11, d f=47)$.

Herbage $\mathrm{N}, \mathrm{P}, \mathrm{K}, \mathrm{Mg}$, and Ca removal, which reflected the combined effect of herbage DM yield and nutrient content, was significantly affected by management $(\mathrm{N}$, $\mathrm{P}, \mathrm{K}, \mathrm{Mg}$ ), site (K, Mg, Ca), and M-S interaction (Ca) (Fig. 4). With mowing, the herbage $\mathrm{N}, \mathrm{P}, \mathrm{K}$ and $\mathrm{Mg}$ removal decreased (Table 4), while the herbage Ca removal increased markedly in $\mathrm{S} 1$, due to the increase in forbs proportion.

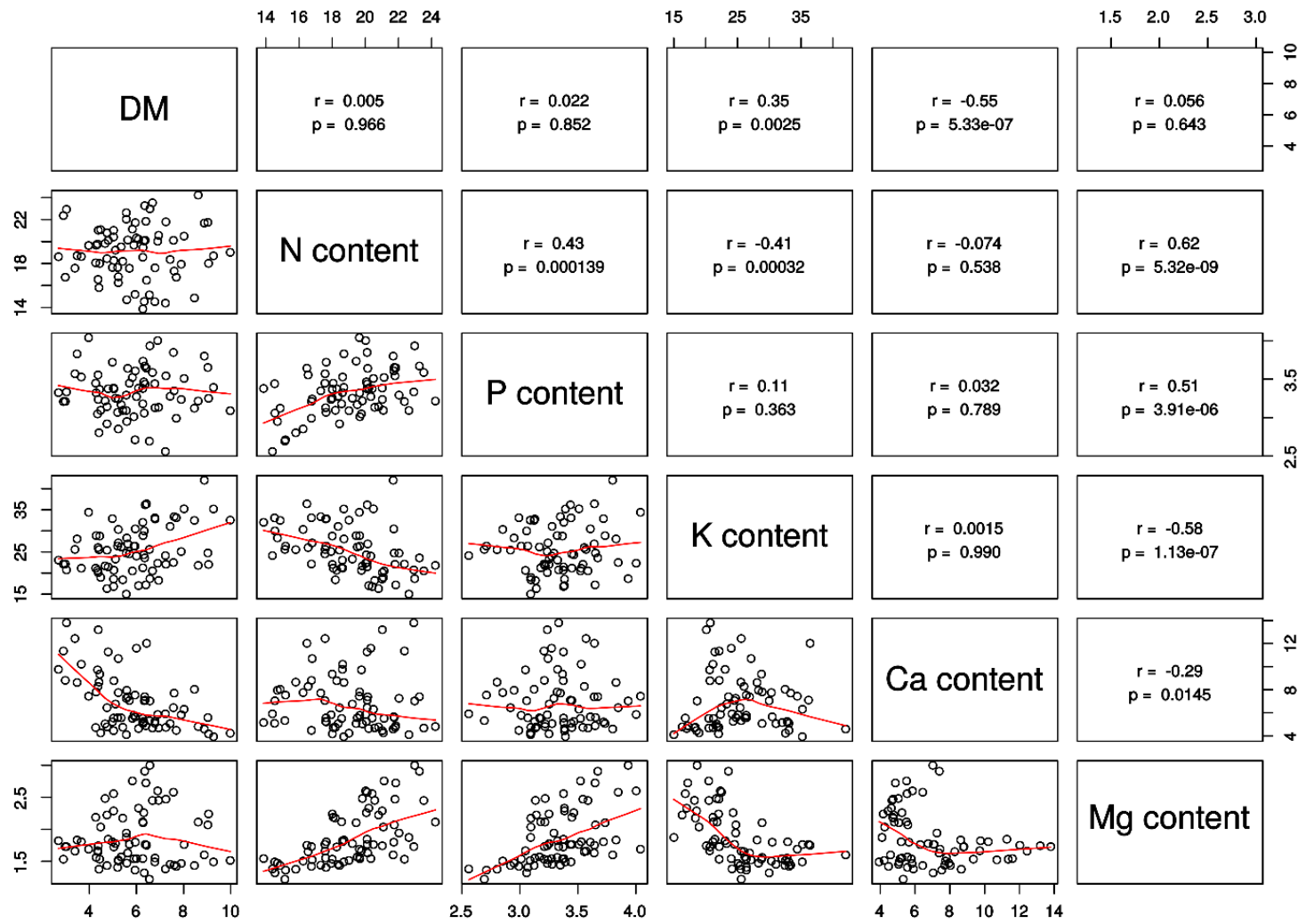

Figure 5. Scatter plots of herbage dry matter yield (DM, tons $\left.\mathrm{ha}^{-1}\right)$ and herbage nutrient content $\left(g \mathrm{~kg}^{-1}\right)$ with correlation among variables. $r$ is Pearson correlation coefficient, $p$ is significance level. Data were fitted by spline model in the scatter plots

Figure 5 shows significant relationships among herbage nutrients. The negative relationship between $\mathrm{K}$ and $\mathrm{Mg}$ content reflected the herbage $\mathrm{K} / \mathrm{Mg}$ antagonistic relationship. The relationship between herbage $\mathrm{N}$ and $\mathrm{K}$ content in $\mathrm{S} 2$ was explained by significant spread of legumes with mowing, which increased the herbage $\mathrm{N}$ content but 
decreased the herbage $\mathrm{K}$ content. The mean herbage $\mathrm{N}$ content of $<20-22 \mathrm{~g} \mathrm{~kg}^{-1}$ in all sites was considered deficient for herbage production. The lowest herbage $\mathrm{N}$ content, seen in S1 under both managements, was negatively correlated with the herbage DM yield ( $r=-0.53, p<0.001, F=18.20, d f=47$ ) induced by the dilution effect, i.e., a decrease in herbage nutrient content with the progressive accumulation of above-ground biomass. Similarly, nutrient ratios showed plant growth $\mathrm{N}$ limitation indicated by N:P $\leq$ 10 and $\mathrm{N}: \mathrm{K}<2.1$ in all sites and both managements. Other type of nutrient limitations did not occur.

Forage value was significantly affected by site. The highest FV was observed in nutrient rich S1. Mowing in all sites was associated with a steady FV decline throughout the study period by approximately 10 points.

The tetany ratio was significantly affected by management, site, and M-S interaction (Fig. 6, Table 3). The tetany ratio was significantly declined with mowing (Fig. 6, Table 4 ). The highest tetany ratio in S1 (in grazed parts $>2.2$ ) was caused primarily by high herbage K content. Lower tetany ratio, observed in S2 and S3, resulted from a mixed effect of lower herbage $\mathrm{K}$ content and higher herbage Ca content (S2) or Mg content (S3). The increase of tetany ratio coincided positively with herbage dry matter yield $(r=$ $0.63, p<0.001, F=91.09, d f=143)$.

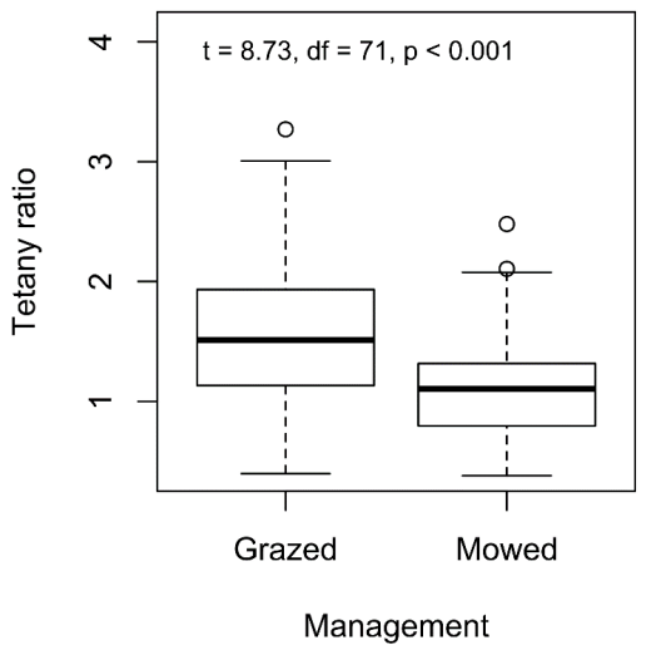

Figure 6. Tetany ratio associated with management

\section{Species richness, Shannon-Wiener index, and Ellenberg $N$ indicator values}

Over years and across sites, mowing increased species richness and SW index compared to grazing (Tables 3, 4, Fig. 7). Both species richness and the SW index were substantially higher in S2 compared to S1 and S3 (mean of both managements), which may be attributed to lower cattle SR and available soil nutrients, combined with mowing in S2. In S1 and S2, mowing was associated with significantly higher species richness compared to the mowed section in S3.

The significant effect of management and site on EIV-N was revealed (Fig. 8). Nutrient removal by mowing reduced EIV-N (Table 4, Fig. 8). The highest EIV-N, seen in S1, were probably linked with the highest SR and soil nutrient levels. Nitrophilous species proliferated considerably in S1 (Lolium perenne, Anthriscus sylvestris, Heracleum sphondylium) compared to the more valuable forage species (Lathyrus 
pratensis, Vicia sativa, Lotus corniculatus, Tragopogon pratensis) found in S2. Conversely, the lowest EIV-N, showing the steepest decline throughout the trial, was recorded in S2 with medium nutrient availability and low SR combined with mowing. The Ellenberg $\mathrm{N}$ values were correlated negatively with species richness $(r=-0.49, p<$ $0.000, F=22.13, d f=71)$.

a)

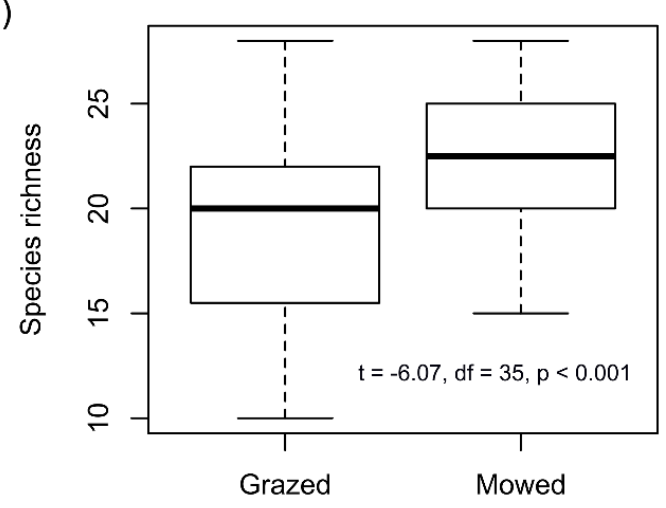

b)

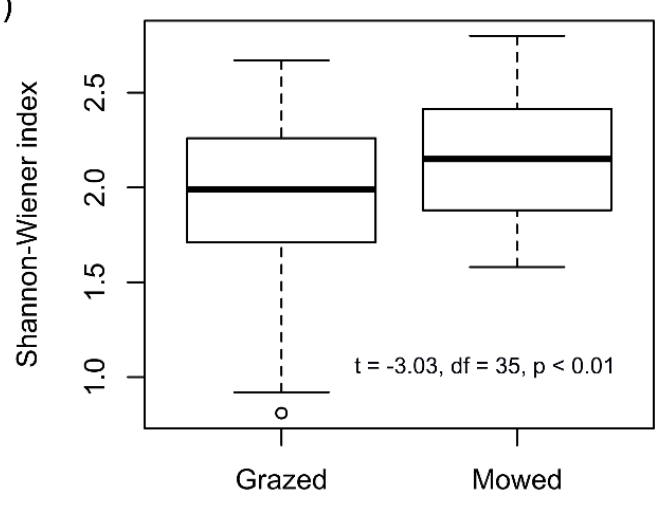

Management

Figure 7. Species richness per $16 \mathrm{~m}^{2}(a)$ and Shannon-Wiener index (b) associated with management

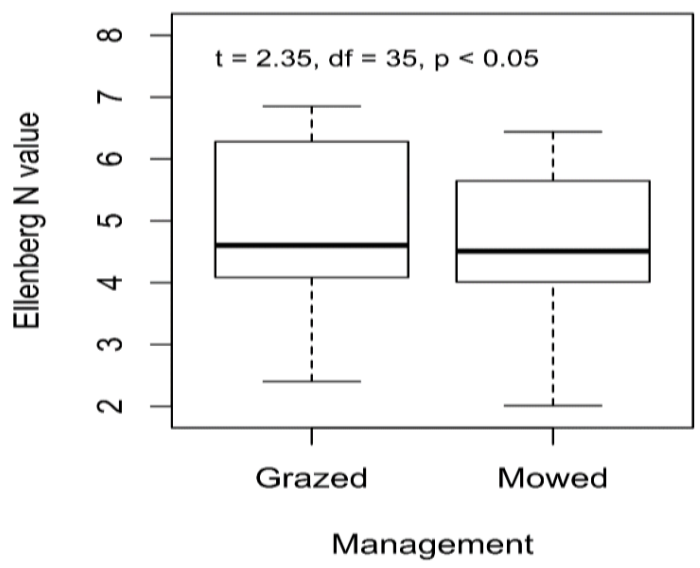

Figure 8. Ellenberg $N$ values associated with management

Parameters obtained from the first phytocenological assessment (species richness, SW index, FV, EIV-N) were correlated with plant functional composition, herbage DM yields and nutrient contents of the first biomass sampling. Proportion of graminoids correlated negatively with species richness $\left(\mathrm{r}=-0.55^{* *}, d f=17\right)$ and $\mathrm{S}-\mathrm{W}$ index ($0.72 * * *, d f=17)$. Similarly, herbage DM yield was linked negatively with species richness $\left(-0.54^{*}, d f=23\right)$. Conversely, both species richness and SW index correlated positively with herbage Ca content $\left(0.58^{* *}, d f=17\right.$ and $0.66^{* *}, d f=17$, respectively) and $\mathrm{S}-\mathrm{W}$ index reflected the increase in proportion of legumes $\left(0.81^{* * *}, d f=17\right)$. Forage value increased along with herbage DM yield $\left(0.63^{* * *}, d f=23\right)$, but declined due to increase in herbage Ca content $\left(-0.60^{* *}, d f=17\right)$. 


\section{Discussion}

Our results summarize that short-term grazing exclusion with mowing can increase biodiversity parameters together with maintenance of agronomic demands in sites with different soil nutrient availability (including nutrient rich S1) and grazing types (twice yearly rotational grazing in S1 and mixed grazing types combined with mowing in S2). The only restriction, which prevented from biodiversity improvement via mowing, was high soil P availability supporting markedly spreading of competitive graminoids (S3). The increase of species richness linked with mowing was induced by changes in plant functional composition (i.e. by a decrease in cover of graminoids and an increase in cover of legumes and forbs) accompanied by acceptable herbage productivity and forage values.

\section{Parameters of agronomic demands}

High soil available P in S3 was responsible for grass species spreading in both mowed and grazed sections at the expense of forbs and legumes (Marriott et al., 2005; Hejcman et al., 2007). In contrast, in S1, and especially in S2, reduced P availability supported the decrease of graminoids related to mowing, which enabled forbs to regenerate to a greater extent than seen with grazing (Hejcman et al., 2007; Blüthgen et al., 2012). Cover of legumes were suppressed by mowing in high yielding S1 and S3, not only by decline in $\mathrm{Mg}$ availability, but likely - except climbing L. pratensis - by lack of light and defoliation (Marriot et al., 2009). The substantial increase of legumes in the exclusively mowed section of $\mathrm{S} 2$ correlating with soil $\mathrm{K}$ availability could be favoured by better light conditions (Kayser and Isselstein, 2005; Gilhaus et al., 2014).

Despite soil nutrient removal by mowing, water and nutrient availability was sufficient to keep herbage DM yields above 4 tons ha $^{-1}$; hence, the grassland types observed in the experiment could be considered highly productive (Hrevušová et al., 2015). Grazing provided higher herbage DM yields, even though lower yields of pastures than of meadows are usually reported due to livestock trampling and more frequent defoliation leading to photosynthesis restriction (Whitehead, 2000; Mládková et al., 2015). Even if 60-99\% of nutrients ingested by livestock are returned to pasture in urine and manure (Jones and Tracy, 2014), distinct ratio of nutrients in excreta (P removal in animal body) than in forage decreases their effective utilization. Our opposite results could be related to quite low SR not leading to frequent trampling and defoliation and also to the type of methodology.

The highest yield, in grazed S1, was related to high nutrient availability (con $\mathrm{N}$ ), maintaining almost the same herbage DM yields during the first three years after grazing was replaced by mowing. In S2 and S3, in which available nutrient levels were lower due to lower SR, herbage DM yield reduction with mowing was more pronounced. The observed inter-annual variability in herbage production is a common feature of all grassland types in Central Europe, primarily related to water supply (Pavlů et al., 2011).

Not only mowing, which decreased the proportion of graminoids, but also the type of grazing management affected the abundance of grasses. Tall grasses sensitive to frequent defoliation were in accordance with Pavlů et al. (2003) more abundant in rotationally grazed S1 compared to S3, where short grasses prevailed under continuous grazing. 
No significant differences in the herbage $\mathrm{N}$ content were observed between managements. This could be explained by the substantial increase of legumes in the mowed section of $\mathrm{S} 2$, which increased herbage $\mathrm{N}$ content due to $\mathrm{N}_{2}$-fixing bacteria (Rose et al., 2012; Klaus et al., 2013b), while the herbage N content decreased with mowing in S1 and S3 with negligible proportion of legumes (Jones and Tracy, 2014). Nitrogen limitation of herbage production was indicated not only by the herbage $\mathrm{N}$ content, but also by the $\mathrm{N}: \mathrm{P}(3.8-7.5)$ and $\mathrm{N}: \mathrm{K}$ ratios (0.37-1.51) (Koerselman and Mueleman, 1996; Güssewell, 2004). In addition, in half the samples, mainly from S1 and S2, N was below the optimal range for dairy cattle of 19.2-25.6 $\mathrm{g} \mathrm{kg}^{-1}$ (Whitehead, 2000). Nitrogen deficiency is common in pasture biomass (Mackay et al., 1995; Klaus et al., 2013a) and regulates other nutrient acquisition and translocation, such as P (Duru and Ducrocq, 1996). Hence, the positive relationship between the herbage $\mathrm{N}$ and $\mathrm{P}$ content may be explained by $\mathrm{N}$ deficiency.

Herbage $\mathrm{P}, \mathrm{K}$, and $\mathrm{Mg}$ contents significantly decreased with mowing, but $\mathrm{P}$ and $\mathrm{K}$ contents remained relatively high without any herbage $\mathrm{P}$ and $\mathrm{K}$ limitations. The herbage P content was considered optimal for dairy cattle, being 2.3-3.7 $\mathrm{g} \mathrm{kg}^{-1}$ (Whitehead, 2000). In S3, herbage $\mathrm{P}$ content did not respond to extremely high soil $\mathrm{P}$ availability, further evidence of $\mathrm{P}$ uptake limited by $\mathrm{N}$ deficiency (Mengel and Kirkby, 1987).

Potassium uptake by plants under high $\mathrm{K}$ availability tends to exceed the threshold of physiological need of $28.0 \mathrm{~g} \mathrm{~kg}^{-1}$ (Hejduk, 2011) as shown in both managements of S1. High $\mathrm{K}$ availability supported by urine and manure deposition could result in inadequate uptake of $\mathrm{Ca}$ and $\mathrm{Mg}$, impaired forage quality, and animal health problems related to grass tetany, the incidence of which is related to high plant growth rate (Kayser and Isselstein, 2005; Schonewille, 2013; Jones and Tracy, 2014). The risk of grass tetany (tetany ratio > 2.2) was almost completely eliminated in our study; only grazed parts in S1 with very high soil $\mathrm{K}$ availability revealed tetany ratio slightly over threshold value (2.21).

Herbage Ca content increased with mowing via forbs and legumes spreading (Reid, 1983). Contrarily, low herbage Ca content was linked with a predominance of grasses that are generally $\mathrm{Ca}$ and $\mathrm{Mg}$ poor in comparison to forbs and legumes (Daccord et al., 2001). Grass magnesium absorption is also affected by species. Powell et al. (1978) reported significantly greater $\mathrm{Mg}$ absorption in Dactylis glomerata than in L. perenne.

Along with the decrease in herbage nutrient contents and DM yields seen with mowing, herbage $\mathrm{N}, \mathrm{P}, \mathrm{K}$, and $\mathrm{Mg}$ removal was reduced significantly (Kayser and Isselstein, 2005). Herbage Ca removal increase slightly with mowing in S1 and S2, due to the herbage Ca content increase (Reid, 1983).

Forage values ranged from 50 to 75 and were considered good (Grozavu et al., 2010), maintained by the grasses Agrostis capillaris, D. glomerata, Poa pratensis, and L. perenne in both managements and Festuca rubra in mowed areas, as well as the forbs Taraxacum sect. Ruderalia in grazed areas and Plantago lanceolata, Achillea millefolium, and Pimpinella major in mowed areas, along with legumes T. repens in grazed areas and $V$. sativa and $T$. pratense in mowed areas, all of which are attractive to animals due to medicinal and aromatic characteristics (Mládek et al., 2006). Legumes also are characterized by high protein and mineral contents. Similar to results of Hakrová et al. (2015), FV was found to decrease with increase in forbs. On the other hand, forbs improve livestock health, immunity, and forage consumption via aromatic substances (Mládek et al., 2006). 


\section{Plant diversity}

In agreement with Blüthgen et al. (2012) and Klaus et al. (2013a), land use and management were recognized as the major drivers of changes in plant diversity. Management regime is closely associated with herbage productivity, which is largely negatively related to plant species richness, often inter-correlated with herbage nutrient contents. In agreement with that, we recognized that plant species richness increased via suppressed competitive ability of grasses and spread of less productive forbs in mowed parts in S1 and S2, which was associated with the herbage $\mathrm{Ca}$ content increase (Duffková and Libichová, 2013; Duffková et al., 2015).

Due to more intense nutrient supply by pasturing before the study, species richness and SW index in mowed plots of S1 and S3 had lower values than grazed area of S2 with lower nutrient supply and occasional mowing (Marriot et al., 2009).

In addition, there are other important factors such as soil site properties $(\mathrm{pH}$ and available nutrients), which determine plant species richness. High soil P availability was designated as an important factor relating negatively to species richness (Hejcman et al., 2010; Merunková and Chytrý, 2012). Hence, the lack of increase in species numbers, along with the high proportion of graminoids under mowing in S3 may be explained by the extremely high $\mathrm{P}$ availability, which allowed highly productive species to dominate (Hejcman et al., 2007). Phosphorus persists in the soil unaffected for decades and thus, it is not worth trying short-term mowing as a tool for plant diversity improvement in such sites (Semelová et al., 2008).

High soil $\mathrm{K}$ availability in $\mathrm{S} 1$ provided sufficient $\mathrm{K}$ supply for forbs increase together with decreased productivity and better light conditions in mowed plots (Elberse et al., 1983).

In accordance with Briemle et al. (2002), the adaptation to more intensive grazing in $\mathrm{S} 1$ and S3 was pronounced for cover of low-growing rosette legume T. repens, which decreased in mowed parts under lower soil Mg content. Spread of nitrophilous species in S1 was observed as a consequence of soil nutrient supply by cattle excrements (Plantureux et al., 2005).

The highest EIV-N (S1) were associated with broad nutrient supply (Blüthgen et al., 2012) and endozoochorous dispersal (Albert et al., 2015). Conversely, the lowest EIV-N (S2) in the exclusively mowed section reflected previously low SR.

\section{Conclusions}

A four-year experiment conducted in upland pasture found herbage DM yield, herbage nutrient contents $(\mathrm{K}, \mathrm{P})$ and nutrient removal $(\mathrm{N}, \mathrm{P}, \mathrm{K}, \mathrm{Mg})$ to be decreased by mowing twice a year replacing low intensity cattle grazing, but these agronomic factors remained acceptable for dairy cattle nutrition. Although our set of data was limited, such clear benefits as wider plant diversity related to legume and forb spreading and the elimination of the risk of grass tetany (i.e. tetany ratio < 2.2) with mowing were associated with a herbage $K$ decrease and increase in herbage Ca content. To reconcile biodiversity and agricultural targets on pastures, a compromise between maintaining grassland species richness and herbage properties according to site-specific conditions may be required. Our findings on short-term grassland management changes are relevant to farmers' priorities when they operate within sustainable agro-environmental schemes. 
Acknowledgments. This research was supported by National Agency of Agricultural Research Grant No. QI 111C034, Institutional support of Ministry of Agriculture No. RO0216, and by Grant Agency of University of South Bohemia in České Budějovice GAJU 081/2016/Z. Special thanks to Zuzana Sýkorová for help with the fieldwork and Kathleen Hills \& Alan Pike for language corrections.

\section{REFERENCES}

[1] Albert, A., Auffret, A. G., Cosyns, E., Cousins, S. A. O., D’hondt, B., Eichberg, C., Eycott, A. E., Heinken, T., Hoffmann, M. et al. (2015): Seed dispersal by ungulates as an ecological filter: a trait-based meta-analysis. - Oikos 124: 1109-1120.

[2] Blüthgen, N., Dormann, C. F., Prati, D. et al. (2012): A quantitative index of land-use intensity in grasslands: Integrating mowing, grazing and fertilization. - Basic and Applied Ecology 13: 207-220.

[3] Briemle, G., Nitsche, S., Nitsche, L. (2002): Grassland utilization indicator values for vascular plant species. - SchrReihe Vegkd 38: 203-225.

[4] Daccord, R., Arrigo, Y., Kessler, J., Jeangros, B., Scehovic, J., Schubiger, F. X., Lehmann, J. (2001): Nutritive value of grassland plants: Contents of calcium, phosphorus, magnesium and potassium. - Agrarforschung 8: 264-269.

[5] Dubeux, J. C. B. Jr, Sollenberger, L. E., Vendramini, J. M. B., Interrante, S. M., Lira, M. A. Jr (2014): Stocking method animal behaviour and soil nutrient redistribution: How are they linked? - Crop Science 54: 2341-2350.

[6] Duffková, R., Libichová, H. (2013): Effects of cattle slurry application on plant species composition of moderately moist Arrhenatherion grassland. - Plant Soil and Environment 59: 485-491.

[7] Duffková, R., Hejcman, M., Libichová, H. (2015): Effect of cattle slurry on soil and herbage chemical properties yield nutrient balance and plant species composition of moderately dry Arrhenatherion grassland. - Agriculture Ecosystems \& Environment 213: 281-289.

[8] Duru, M., Ducrocq, H. (1996): A nitrogen and phosphorus herbage nutrient index as a tool assessing the effect of $\mathrm{N}$ and $\mathrm{P}$ supply on the dry matter yield of permanent pastures. - Nutrient Cycling in Agroecosystems 47: 59-69.

[9] Elberse, W. T., van den Bergh, J. P., Dirven, J. G. P. (1983): Effects of use and mineral supply on the botanical composition and yield of old grassland on heavy clay soil. Netherlands Journal of Agricultural Science 31: 62-88.

[10] Ellenberg, H., Weber, H. E., Düll, R., Wirth, V., Werner, W., Paulissen, D. (1992): Zeigerwerte von Pflanzen in Mitteleuropa (2nd ed.). - Scripta Geobotanica 18: 1-258.

[11] GenABEL project developers (2013): GenABEL: genome-wide SNP association analysis R package CRAN. http://CRANR-projectorg/package=GenABEL.

[12] Gilhaus, K., Hölzel, N. (2016): Seasonal variations of fodder quality and availability as constraints for stocking rates in year-round grazing schemes. - Agriculture Ecosystems \& Environment 234: 5-15.

[13] Gilhaus, K., Stelzner, F., Hölzel, N. (2014): Cattle foraging habits shape vegetation patterns of alluvial year-round grazing systems. - Plant Ecology 215: 169-179.

[14] Gilhaus, K., Freitag, M., Kunze, S., Hölzel, N. (2017): High fodder value and feeding likelihood favour endozoochorous plat dispersal. - Journal of Vegetation Science 28: 357-367.

[15] Grozavu, C., Pop, I. M., Radu-Rusu, C. G. (2010): Researches concerning the floral composition and grazing value of an Agrostis tenuis-Festuca rubra pasture from VânătoriNeamţ Natural Park. - Lucrări ştiinţifice seria zootehnie 53: 391-395.

[16] Güsewell, S. (2004): N:P ratios in terrestrial plants: variation and functional significance. - New Phytologist 164: 243-266. 
[17] Hakrová, P., Novotná, K., Sýkorová, Z., Frelich, J. (2015): Ecological-agricultural perspective on the quality of pasture vegetation. - Journal of Central European Agriculture 16: 225-234.

[18] Hejcman, M., Klaudisová, M., Schellberg, J., Honsová, D. (2007): The Rengen Grassland Experiment: plant species composition after 64 years of fertilizer application. Agriculture Ecosystems \& Environment 122: 259-266.

[19] Hejcman, M., Schellberg, J., Pavlů, V. (2010): Long-term effects of cutting frequency and liming on soil chemical properties biomass production and plant species composition of Lolio-Cynosuretum grassland after the cessation of fertilizer application. - Applied Vegetation Science 13: 257-269.

[20] Hejduk, S. (2011): Changes of soil agrichemical characteristics in pastures influenced by mineral fertilizing. - Acta Universitatis Agriculturae et Silviculturae Mendelianae Brunensis 59: 113-120.

[21] Hrevušová, Z., Hejcman, M., Hakl, J., Mrkvička, J. (2015): Soil chemical properties plant species composition herbage quality production and nutrient uptake of an alluvial meadow after 45 years of N, P and K application. - Grass and Forage Science 70: 205218.

[22] ISO 11261 (1995): Soil quality - Determination of total nitrogen - Modified Kjeldahl method. - International Organization for Standardization, Geneva.

[23] Isselstein, J., Jeangros, B., Pavlů, V. (2005): Agronomic aspects of biodiversity targeted management of temperate grasslands in Europe - A review. - Agronomy Research 3: 139-151.

[24] Jones, G. B., Tracy, B. F. (2014): Pasture soil and herbage nutrient dynamics through five years of rotational stocking. - Crop Science 54: 2351-2361.

[25] Kayser, M., Isselstein, J. (2005): Potassium cycling and losses in grassland systems: a review. - Grass and Forage Science 60: 213-224.

[26] Klaus, V. H., Hölzel, N., Boch, S., Müller, J., Socher, S. A., Prati, D., Fischer, M., Kleinebecker, T. (2013a): Direct and indirect associations between plant species richness and productivity in grasslands: regional differences preclude simple generalization of productivity-biodiversity relationships. - Preslia 85: 97-112.

[27] Klaus, V. H., Kleinebecker, T., Prati, D., Gossner, M., Alt, F., Boch, S., Gockel, S., Hemp, A., Lange, M., Müller, J., Oelmann, Y., Pašalić, E., Renner, S. C., Socher, S. A., Türke, M., Weisser, W. W., Fischer, M., Hölzel, N. (2013b): Does organic grassland farming benefit plant and arthropod diversity at the expense of yield and soil fertility? Agriculture Ecosystems \& Environment 177: 1-9.

[28] Koerselman, W., Meuleman, A. F. M. (1996): The vegetation N:P ratio: a new tool to detect the nature of nutrient limitation. - Journal of Applied Ecology 33: 1441-1450.

[29] Kubát, K., Hrouda, L., Chrtek, J. Jr, Kaplan, Z., Kirschner, J., Štěpánek, J. (eds.) (2002): Klíč ke květeně České republiky [Key to the flora of the Czech Republic]. - Academia, Praha, 928 pp. [in Czech].

[30] Mackay, A. D, Saggar, S., Trolove, S. N., Lambert, M. G. (1995): Use of an unsorted pasture sample in herbage testing for sulphur phosphorus and nitrogen. - New Zealand Journal of Agricultural Research 38: 483-493.

[31] Marriott, C. A., Bolton, G. R., Fisher, J. M., Hood, K. (2005): Short-term changes in soil nutrients and vegetation biomass and nutrient content following the introduction of extensive management in upland sown swards in Scotland UK. - Agriculture Ecosystems \& Environment 106: 331-344.

[32] Marriot, C. A., Hood, K., Fisher, J. M., Pakeman, R. J. (2009): Long-term impact of extensive grazing and abandonment on the species composition richness diversity and productivity of agricultural grassland. - Agriculture Ecosystems \& Environment 134: 190-200.

[33] Mengel, K., Kirkby, E. A. (1987): Principles of plant nutrition. - International Potash Institute, Bern, 3rd ed., 655 pp. 
[34] Merunková, K., Chytrý, M. (2012): Environmental control of species richness and composition in upland grassland of the southern Czech Republic. - Plant Ecology 213: 591-602.

[35] Mládek, J., Pavlů, V., Hejcman, M., Gaisler, J. (2006): Pastva jako prostředek údržby trvalých travních porostů $\mathrm{v}$ chráněných územích [Grazing as a tool of maintenance of permanent grasslands in protected areas]. Methodology, Crop Research Institute, Prague, 104 pp. [in Czech].

[36] Mládková, P., Mládek, J., Hejduk, S., Hejcman, M., Cruz, P., Jouany, C., Pakeman, R. J. (2015): High-nature-value grasslands have the capacity to cope with nutrient impoverishment induced by mowing and livestock grazing. - Journal of Applied Ecology 52: 1073-1081.

[37] Olde Venterink, H., Karde, I., Kotowski W., Peeters W., Wassen, M. J. (2009): Longterm effects of drainage and hay-removal on nutrient dynamics and limitation in the Biebrza mires, Poland. - Biogeochemistry 93: 235-252.

[38] Pavlů, V., Hejcman, M., Pavlů, L., Gaisler, J. (2003): Effect of rotational and continuous grazing on vegetation of an upland grassland in the Jizerske hory Mts., Czech Republic. Folia Geobotanica 38: 21-34.

[39] Pavlů, V., Hejcman, M., Pavlů, L., Gaisler, J., Nežerková, P. (2006): Effect of continuous grazing on forage quality quantity and animal performance. - Agriculture Ecosystems \& Environment 113: 349-355.

[40] Pavlů, V., Schellberg, J., Hejcman, M. (2011): Cutting frequency versus N application effect of twenty years management on Lolio-Cynosuretum grassland. - Grass and Forage Science 66: 501-515.

[41] Pinheiro, J., Bates, D., DebRoy, S., Sarkar, D. (2016): R Core Team 2016 nlme: Linear and Nonlinear Mixed Effects Models $R$ package CRAN. http://CRANRprojectorg/package $=$ nlme

[42] Plantureux, S., Peeters, A., McCracken, D. (2005): Biodiversity in intensive grasslands: Effect of management improvement and challenges. - Agronomy Research 3: 153-164.

[43] Powell, K., Reid, R. L., Balasko, J. A. (1978): Performance of lambs on perennial ryegrass smooth bromegrass orchardgrass and tall fescue pastures II. Mineral utilization in-vitro digestibility and chemical composition of herbage. - Journal of Animal Science 46: 1503-1514.

[44] Quan, Q., Nianpeng, H., Zhen, Z., Yunhai, Z., Yang, G. (2015): Nitrogen enrichment and grazing accelerate vegetation restoration in degraded grassland patches. - Ecological Engineering 75: 172-177.

[45] Regal, V. (1980): Ecological and biological bases of meadow science. - In: Klesnil, A. (ed.) Pícninářství II [Forage Crop II]. AF VŠZ, Praha, pp. 18-49 [in Czech].

[46] Reid, R. L. (1983): Biological availability of magnesium from natural and supplemental sources. - In: Bunce, G. E., Webb, K. E. Jr, Allen, V. G. (eds.) Role of magnesium in animal nutrition fontenot JP - Polytechnic Institute State University Blacksburg, Blacksburg VA, pp. 121-142.

[47] Rose, L., Hertel, D., Leuschner, C. (2012): Livestock-type effects on biomass and nitrogen partitioning in temperate pastures with different functional-group abundance. Grass and Forage Science 68: 386-394.

[48] Sanderson, M. A., Skinner, R. H., Barker, D. J., Edwards, G. R., Tracy, B. F., Wedin, D. A. (2004): Plant species diversity and management of temperate forage and grazing land ecosystems. - Crop Science 44: 1132-1144.

[49] Sáňka, M., Materna, J. (2004): Indikátory kvality zemědělských a lesních půd Č [Quality indicators of agricultural and forest soils of the Czech Republic]. Edition Planet 2004 (12), Ministry of the Environment, Praha [in Czech].

[50] Schonewille, J. T. (2013): Magnesium in dairy cow nutrition: an overview. - Plant Soil 368: 167-178. 
[51] Semelová, V., Hejcman, M., Pavlů, V., Vacek, S., Podrázský, V. (2008): The Grass Garden in the Giant Mts. (Czech Republic): residual effect of long-term fertilization after 62 years. - Agriculture Ecosystems \& Environment 123: 337-342.

[52] Veselá, M., Mrkvička, J., Šantrůček, J., Štráfelda, J., Velich, J., Vrzal, J. (2009): Návody ke cvičení z pícninářství [Manuals for the exercise of forage crop]. Textbooks of FAFNR, Czech University of Life Science, Prague, 202 pp. [in Czech].

[53] Whitehead, D. C. (2000): Nutrient elements in grassland: soil-plant-animal relationships. CAB International, Wallingford UK.

[54] Wrage, N., Strodthoff, J., Cuchillo, H. M., Isselstein, J., Kayser, M. (2011): Phytodiversity of temperate permanent grasslands: ecosystem services for agriculture and livestock management for diversity conservation. - Biodiversity and Conservation 20: 3317-3339.

[55] Zhang, H., Gilbert, B., Wang, W., Liu, J., Zhou, S. (2013): Grazer exclusion alters plant spatial organization at multiple scales increasing diversity. - Ecology and Evolution 3: 3604-3612 